\title{
Groundwater uptake of forest and agricultural land covers in regions of recharge and discharge
}

\author{
Norbert Móricz ${ }^{(1)}$, Tibor Tóth ${ }^{(2)}$, \\ Kitti Balog ${ }^{(2)}$, András Szabó ${ }^{(1)}$, \\ Ervin Rasztovits ${ }^{(1)}$, Zoltán \\ Gribovszki $^{(3)}$
}

\begin{abstract}
Groundwater uptake of vegetation in discharge regions is known to play an important role, e.g., in the Hungarian Great Plain. Nevertheless, only little detailed monitoring of water table fluctuations and groundwater uptake $\left(E T_{\mathrm{gw}}\right)$ were reported under varying hydrologic conditions and vegetation cover. In this study, results of water table monitoring under forest plantations and adjacent corn plots in discharge and recharge regions were analyzed to gain better understanding of the relation of vegetation cover to groundwater uptake. A poplar (Populus tremula) plantation and adjacent corn field plot were surveyed in a local discharge area, while a black locust (Robinia pseudoacacia) plantation and adjacent corn field plot were analyzed in a recharge area. The water table under the poplar plantation displayed a night-time recovery in the discharge region, indicating significant groundwater supply. In this case an empirical version of the water table fluctuation method was used for calculating the $\mathrm{ET}_{\mathrm{gw}}$ that included the groundwater supply. The mean $\mathrm{ET}_{\mathrm{gw}}$ of the poplar plantation was $3.6 \mathrm{~mm} \mathrm{day}^{-1}$, whereas no water table fluctuation was observed at the nearby corn plot. Naturally, the root system of the poplar was able to tap the groundwater in depths of 3.0-3.3 $\mathrm{m}$ while the shallower roots of the corn did not reach the groundwater reservoir in depths of 2.7-2.8 m. In the recharge zone the water table under the black locust plantation showed step-like changes referring to the lack of groundwater supply. The mean $\mathrm{ET}_{\mathrm{gw}}$ was $0.7 \mathrm{~mm} \mathrm{day}^{-1}$ (groundwater depths of 3.0-3.2 m) and similarly no $\mathrm{ET}_{\mathrm{gw}}$ was detected at the adjacent corn plot with groundwater depths between 3.2 and $3.4 \mathrm{~m}$. The low $\mathrm{ET}_{\mathrm{gw}}$ of the young black locust plantation was due to the lack of groundwater supply in recharge area, but also the shallow root system might have played a role. Our results suggest that considerations should be given to local estimations of $\mathrm{ET}_{\mathrm{gw}}$ from water table measurements that could assist to better understanding of groundwater use of varying vegetation types in recharge and discharge zones.
\end{abstract}

Keywords: Groundwater, Evapotranspiration, Poplar, Black Locust, Recharge and Discharge Area

pleted from the groundwater.

Discharge and recharge regions of groundwater can be identified by changes of water table levels with depth, surface water networks and vegetation patterns (Toth 1962, 1963). In discharge regions the net saturated flow of groundwater is directed upward. The water table is close to the surface, thus the vegetation often rely

$\square$ (1) Forest Research Institute, National Agricultural Research and Innovation Centre, Sárvár (Hungary); (2) Institute for Soil Sciences and Agricultural Chemistry, Centre for Agricultural Research, Hungarian Academy of Sciences, Budapest (Humgary); (3) Institute of Geomatics and Civil Engineering, University of West Hungary, Sopron (Hungary)

@ Norbert Móricz (calvus0919@gmail.com)

Received: Sep 08, 2015 - Accepted: Jan 19, 2016

Citation: Móricz N, Tóth T, Balog K, Szabó Aá, Rasztovits E, Gribovszki Zá (2016). Groundwater uptake of forest and agricultural land covers in regions of recharge and discharge. iForest (early view). - doi: 10.3832/ifor1864-009 [online 2016-05-17]

on the groundwater (Ijjász 1939, Magyar 1961). Recharge areas occur where the net saturated flow of groundwater is directed away from the water table (Freeze 1969). In these areas the groundwater is seldom available for the vegetation to transpire.

Evapotranspiration (ET) by local phreatophytic vegetation is one of the primary processes of natural groundwater discharge. In discharge regions the plants often meet their water demands partly directly from the groundwater via their root systems, thereby inducing a diel signal of the water table which is characterized by an early morning maximum and an afternoon minimum in the groundwater level (Loheide et al. 2005, Butler et al. 2007, Shah et al. 2007, Lautz 2008). The high ET of vegetation creates local depression of groundwater, which enhances the subsurface flow and further support the ET. In discharge regions, comparative groundwater ET studies showed a two- to three-fold difference in groundwater $\mathrm{ET}\left(\mathrm{ET}_{\mathrm{gw}}\right)$ between forests and the nearby land cover (Schilling 2007, Móricz et al. 2012, Gribovszki et al. 2014). 
Fig. 1 - Map of land use, elevation and location of monitoring plots with GW wells. Poplar plot well is indicated by F2, black locust plot well by F6 and the corn plots by $\mathrm{F}_{3}$ and F7.
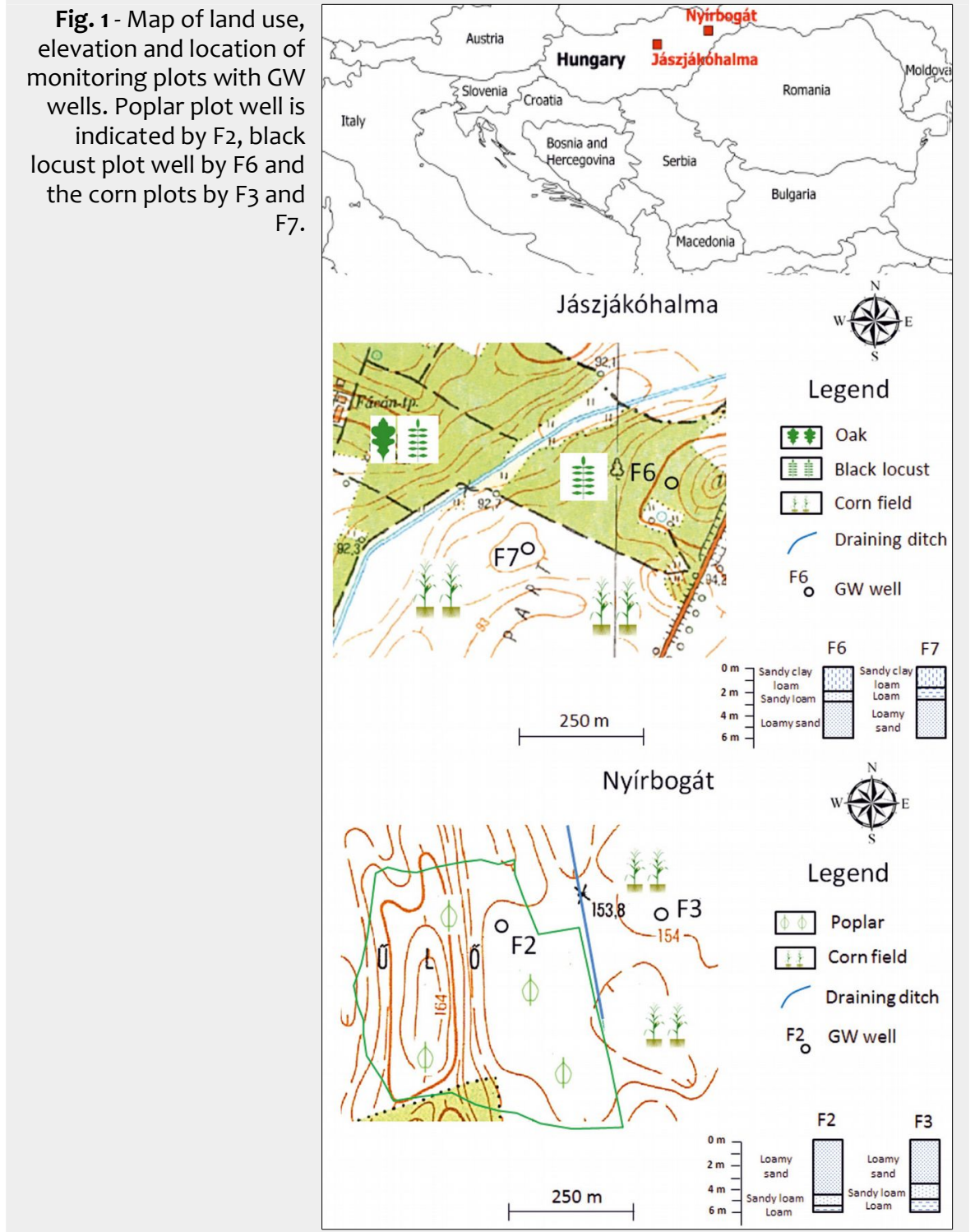

Legend

Schilling (2007) studied three common riparian land covers (forest, corn and grass) using high-resolution water table measurements in lowa (USA). $\mathrm{ET}_{\mathrm{gw}}$ of forest was found to be significantly higher in mid-July than that of the other land covers (1.6-2.2fold in case of the corn and 2.1-3.5-fold in case of the grass). Móricz et al. (2012) compared the water balance of different land uses (common oak and fallow) in the northeastern part of the Hungarian Great Plain. $\mathrm{ET}_{\mathrm{gw}}$ was three times higher in the oak forest than in the nearby fallow plot, estimated by high temporal resolution groundwater measurements. Gribovszki et al. (2014) examined the effect of forests on groundwater ET in the Jászság region of the Hungarian Great Plain. The water table was about $0.5 \mathrm{~m}$ lower in the forest than under the pasture and the $\mathrm{ET}_{\mathrm{gw}}$ of the oak plot was more than twice (2.3-fold) as large.

In recharge areas where the deep-rooted vegetation is able to tap the groundwater, the typical diurnal water table fluctuation shows a stepped pattern. ET causes the water table to deepen during the day and then the water table remains relatively leveled or slightly deepens during the night. In such upland locations forests face a major threat by drought stress (Breshears et al. 2005, Allen et al. 2010, Matyas \& Sun 2014) due to climate change (Gálos et al. 2007), especially where the roots of trees could hardly tap the groundwater reservoir.

The higher water consumption of forests compared to grasslands and short rotation crops leads to the reduction of water yield (Andréassian 2004, Jobbágy \& Jackson 2004, Nosetto et al. 2005) and causes the drop of water table levels (Major 2002) especially at small catchment scale. However, at larger scales the plantation of additional forests should raise water availability downstream and intensify the hydrological cycle through increased precipitation in the interior of continents. For that reason, water resource management should consider not only the local effect of forests on discharge, but also the products water footprint, the value of ecosystem services, the drought mitigation strategies and the large-scale positive effect of forests on the climate (Falkenmark \& Rockström 2006, Hoekstra et al. 2009, Ellison et al. 2012, Grant et al. 2013).

A wide range of methods for estimating the actual ET are available (Drexler et al. 2004). The remote sensing based evapotranspiration method is cost effective, but captures the ET values on a scale of $1 \mathrm{~km}$ or larger for heterogeneous land cover; thus the ET of small forest patches, agricultural fields or pastures in recharge and discharge zones cannot be analyzed. Often the equipment for actual ET measurement either is not only expensive but also only point measurements are provided. A costeffective approach for estimation of $\mathrm{ET}_{\mathrm{gw}}$ is the use of the diurnal groundwater fluctuations.

Although the importance of groundwater uptake in shallow water table environments of the riparian zones is indisputable, the groundwater uptake of plant communities is rarely studied under various hydrologic conditions (Schilling 2007, Mazur et al. 2013).

In this paper we analyzed the water table fluctuation and the $\mathrm{ET}_{\mathrm{gw}}$ of different vegetation covers (forest vs. agricultural land) in recharge and discharge zones using the diurnal groundwater fluctuation. The novelty of our approach was the employment of different estimation methods for the discharge and recharge areas. Our research focused on the following questions: (1) how water table depth varies over the course of a day under different vegetation types in discharge and recharge areas? (2) How can the groundwater consumption be estimated in these areas? and (3) What are the magnitude of $\mathrm{ET}_{\mathrm{gw}}$ under different vegetation types?

\section{Materials and methods}

\section{Site description}

In the frame of a national project (OTKA NN 79835 project), 108 plots of forested and nearby non-forested sites were investigated. In this paper two pairs of neighboring plots were compared in the Hungarian Great Plain in May-June of 2014. One study site is situated close to Nyírbogát ( $4747^{\prime} \mathrm{N}$, $2201^{\prime} \mathrm{E}$ ), where a 26-year-old poplar (Populus tremula) forest ( $\mathrm{GW}$ well F2, sparse plantation: 312 trees ha $^{-1}$, mean diameter: $0.297 \mathrm{~m}$, height: $22.1 \mathrm{~m}$ ) was analyzed in parallel with a corn field (GW well F3). The other study site is located near to Jászjákóhalma (47 31' N, $\left.2001^{\prime} \mathrm{E}\right)$, where a 12 years old black locust (Robinia pseudoacacia) forest (GW well F6, dense plantation: 8900 trees ha ${ }^{-1}$, mean diameter: $0.129 \mathrm{~m}$, height: $11.4 \mathrm{~m}$ ) and a nearby corn field (GW well F7) were compared (Fig. 1).

The area of Nyírbogát is built up from sandy river deposits of the early Pleistocene (Borsy et al. 1981), but the sand was transported by wind (fluvio-eolian relief) (Balog et al. 2014). Both plots (wells F2 and F3) are situated in a local discharge zone, 
surrounded by higher elevation. Not only the geomorphology and the nearby draining ditch, but also the presence of phreatophytic vegetation indicate the discharge character of these plots. Historically (in the first half of the $20^{\text {th }}$ century) the area of the present poplar forest was grassland, then it was afforested and the preceding tree species was grey poplar (Populus $\times$ canescens) which was logged in 1988.

In contrast the Jászjákóhalma plots (wells F6 and F7) are located in local recharge zone, 3-4 $\mathrm{m}$ above the depression of the nearby draining ditch. The geological basis of this area is fluvial sediments, mainly sand and silt (Fig. 1), in some areas re-transported by wind. The area of the black locust plot was grassland in the first half of the $20^{\text {th }}$ century, then it was transformed into agricultural land and finally it was afforested with black locust 12 years ago.

\section{Data collection}

Meteorological conditions and groundwater level were monitored by automatic equipments. The weather stations (Vantage $\mathrm{Pro}^{\circledR}$, Davis Instruments Co., Hayward, CA, USA) recorded standard meteorological parameters (air temperature, relative humidity, global radiation, wind speed and precipitation) every five minutes. Groundwater wells were installed in each plot (F2, F3, F6, F7) with depth of 6 meters. Groundwater levels were measured by vented pressure transducers (Dataqua Elektronikai Kft., Balatonalmádi, Hungary) with time interval of $15 \mathrm{~min}$.

At each site the mineral soil was sampled with $20 \mathrm{~cm}$ intervals down to $100 \mathrm{~cm}$ depth and with $50 \mathrm{~cm}$ intervals down to the full depth of the wells. Soil texture was determined using grain size distribution measured by the pipette method.

\section{Evapotranspiration calculation}

Diurnal signal of groundwater levels can be detected in areas with shallow groundwater depths due to the daily changes of transpiration during vegetation periods (White 1932, Gribovszki et al. 2010). The amplitude of the signal is determined by the soil texture and magnitude of groundwater uptake. $\mathrm{ET}_{\mathrm{gw}}$ was estimated from groundwater level readings for each plot.

In case of the groundwater discharge area (Nyírbogát) the empirical version of a technique was applied (Gribovszki et al. 2008), based on the White-method (White 1932). The proposed method obtained the highest correlation with evapotranspiration measured at a groundwater lysimeter (Fahle \& Dietrich 2014).

The fundamental assumption was that the groundwater supply per unit area $\left(Q_{\text {net }}\right)$ changes over the day. The maximum value of $Q_{\text {net }}$ was calculated for each day by selecting the largest positive time-rate of change value in the groundwater level readings, while the minimum was obtained by computing the mean of the smallest time-rate of change in the predawn hours, by multiplying it by the value of $S_{y}$ (see below). The values of the minimum and maximum $Q_{\text {net }}$ then were assigned to the locations of the groundwater level extremes. Spline interpolation was applied to interpolate the missing values between the minimum and maximum values.

The $\mathrm{ET}_{\mathrm{gw}}$ rates were obtained as follows (eqn. 1):

$$
E T_{g w}=Q_{n e t}-S_{y} \frac{d W T}{d t}
$$

where $Q_{\text {net }}\left[\mathrm{L}^{3} \mathrm{~T}^{-1}\right]$ is the net groundwater supply, $W T[\mathrm{~L}]$ is the average groundwater level, $t$ is the time, $S_{\mathrm{y}}$ is the readily available specific yield (Loheide et al. 2005), which denotes the amount of water released from the vadose zone during the time frame ( $<12$ hours) of the diurnal fluctuations.

In the groundwater recharge area (Jászjákóhalma) where a step-like pattern of water table was observed, the following formula may be well suited for estimating $\mathrm{ET}_{\mathrm{gw}}$ (eqn. 2):

$$
E T_{g w}=S_{y} \frac{d W T}{d t}
$$

The readily available specific yield was estimated from soil texture data. According to the trilinear diagram of Loheide et al.
(2005), $S_{y}$ varied between 0.21 and 0.28 . Following Meyboom (1967) the $S_{y}$ values were halved to consider the effect of time for drainage.

Rainfall events affect the groundwater uptake estimation through evaporation of intercepted rainfall from the canopy and evaporation loss from topsoil. These days were excluded since neither the rainfall interception nor the soil water content changes of the topsoil were measured.

The reference evapotranspiration of Allen et al. (1998) was calculated using the measured meteorological parameters for grass surface. The estimated ET values were used to calculate correlations with the estimated groundwater uptake values. The strength of the correlations showed the importance of groundwater use.

\section{Results and discussion}

\section{Water table fluctuations and} groundwater supply

During the study period the precipitation was only $30-50 \%$ of the average precipitation sum of May and June in both study sites (Fig. 2).

The water table depression in Nyírbogát $(0.37 \mathrm{~m})$ was similar to the water drop observed by Móricz et al. (2012) in the Nyírség region (about 0.5-0.6 m) while there was no observable depression under the young black locust plantation, probably due to its shallow rooting depth (Keresztesi 1968 - Fig. 2).

In both regions the water table sank considerably more under the forest plantations (poplar: $0.15 \mathrm{~m}^{\text {month }}{ }^{-1}$; black locust: $0.125 \mathrm{~m} \mathrm{month}^{-1}$ ) than under the corn plots (GW well F3: $0.1 \mathrm{~m}^{\text {month }}{ }^{-1}$; GW well F7: $\left.0.075 \mathrm{~m} \mathrm{month}^{-1}\right)$.

In the discharge area the water table under the poplar plantation (GW well F2) increased at night, which combined with the daytime ET draw-down signal, producing the diurnal pattern observed in the hydrograph (Fig. 3). The night-time recovery of the water table was probably due to the upwelling from the aquifer enhanced by the plant draw-down of groundwater.
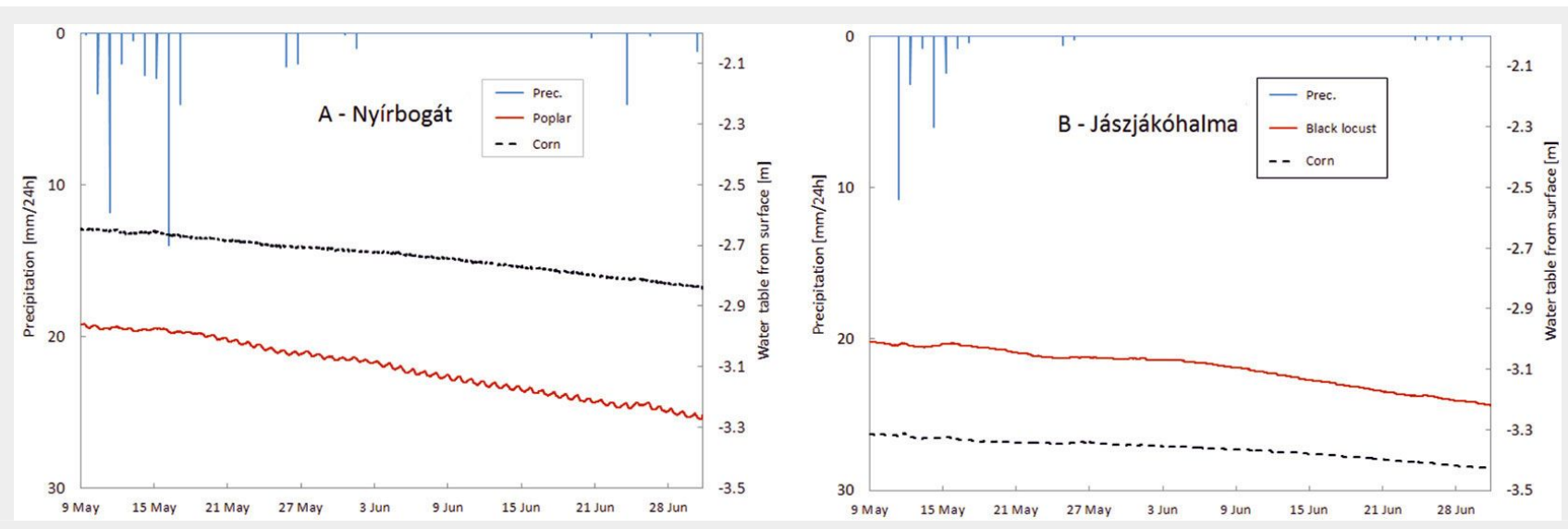

Fig. 2 - Groundwater depths from the surface. Poplar forest (GW well F2) and nearby corn site (GW well F3) in Nyírbogát (A) and the black locust forest (GW well F6) and nearby corn site GW well F7) in Jászjákóhalma (B) (09.05.2014 - 31.06.2014). 
Fig. 3 - Diurnal fluctuations of water table levels of the poplar (GW well F2) and the black locust (GW well F6) plots.

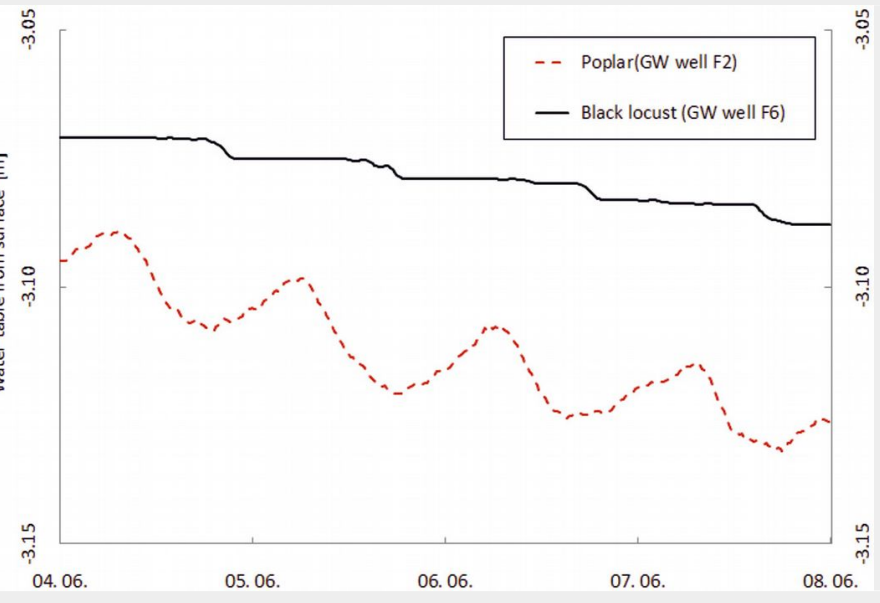

The amplitude of daily water table fluctuation for the poplar was about $1 \mathrm{~cm}$ in the study period. Maximum and minimum groundwater levels were measured around $6 \mathrm{AM}$ and $18 \mathrm{PM}$ respectively. There was no systematic observed diurnal water table fluctuation under the corn plot (GW well F3), since the roots of the corn could not tap the water table.

In the recharge area the diurnal fluctuation under the black locust forest (GW well
F6) was considerably different showing clear step changes (about $0.4 \mathrm{~cm}$ ). The lack of night-time recovery of water table meant that there was no net water supply, but the roots of the trees could tap the groundwater table for evapotranspiration (Fig. 3). The lack of any signal under the corn plot (GW well F7) indicated that the roots of the corn could not use the groundwater for evapotranspiration.

It should be noted that the shape of the observed water table fluctuation is suitable to decide whether a particular location acts as a recharge or discharge zone. However, the groundwater zones are not only spatially variable but are also changing in time. The recharge area could transform to discharge area and vice versa due to changes in water table depth, land cover and climate. For instance afforestation of a recharge zone may cause a water table depression, thereby inducing groundwater supply from the adjacent regions that is characteristic of the discharge zones.

The net groundwater supply displayed a significant daily fluctuation changing between 0.04 and $0.1 \mathrm{~mm} / 30 \mathrm{~min}$ under the poplar plot (GW well F2). In case of the black locust (GW well F6) there was no observed groundwater supply during night hours (Fig. 4). The readily available specific yield values $\left(S_{y}\right)$ presented an uncertainty for the calculations. We used the soil texture to estimate a constant $S_{y}$, but it is known from previous research that $S_{y}$ can be highly variable with water table depth (Duke 1972).

Groundwater evapotranspiration of the poplar and the black locust plantations

The calculated daily groundwater evapo-

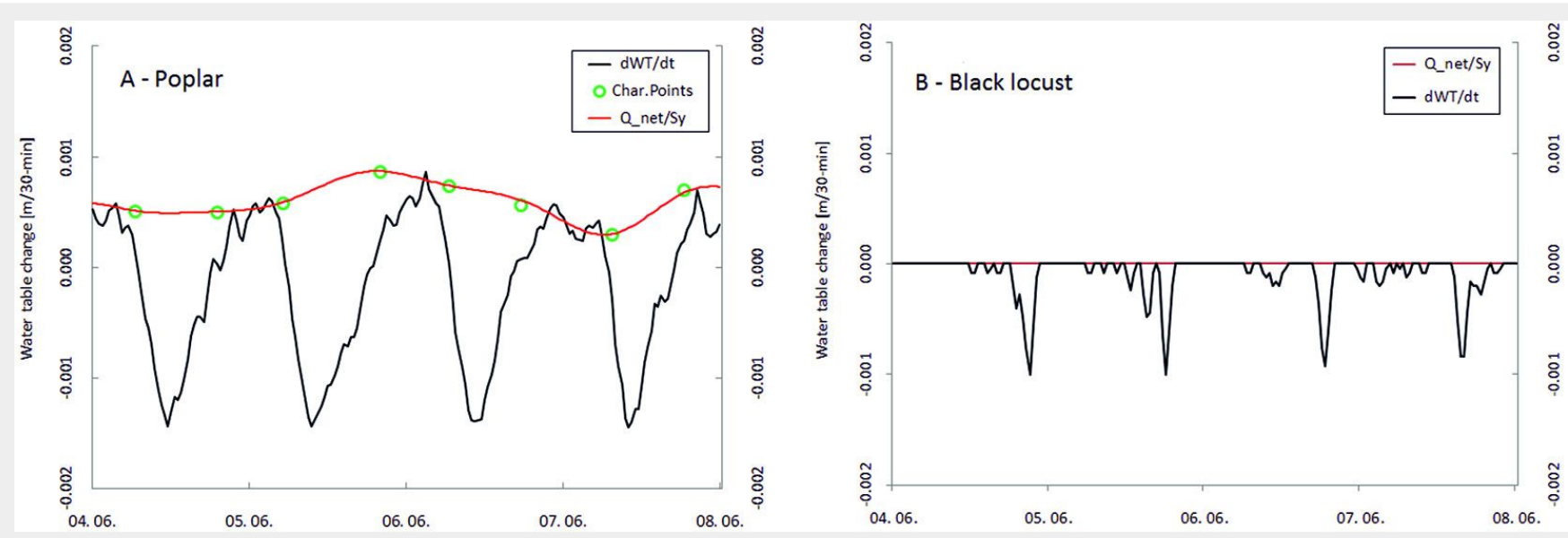

Fig. 4 - Net groundwater supply rate $\left(Q_{\text {net }}\right)$ and water table change. $Q_{\text {net }}$ is divided by $S_{\mathrm{y}}$, the readily available specific yield $\left(Q_{\text {net }} / S_{\mathrm{y}}\right)$, water table change $(d W T / d t)$ and characteristic points of $Q_{\text {net }}$ in the poplar (GW well F2 - A) and black locust (GW well F6 - B) plots.
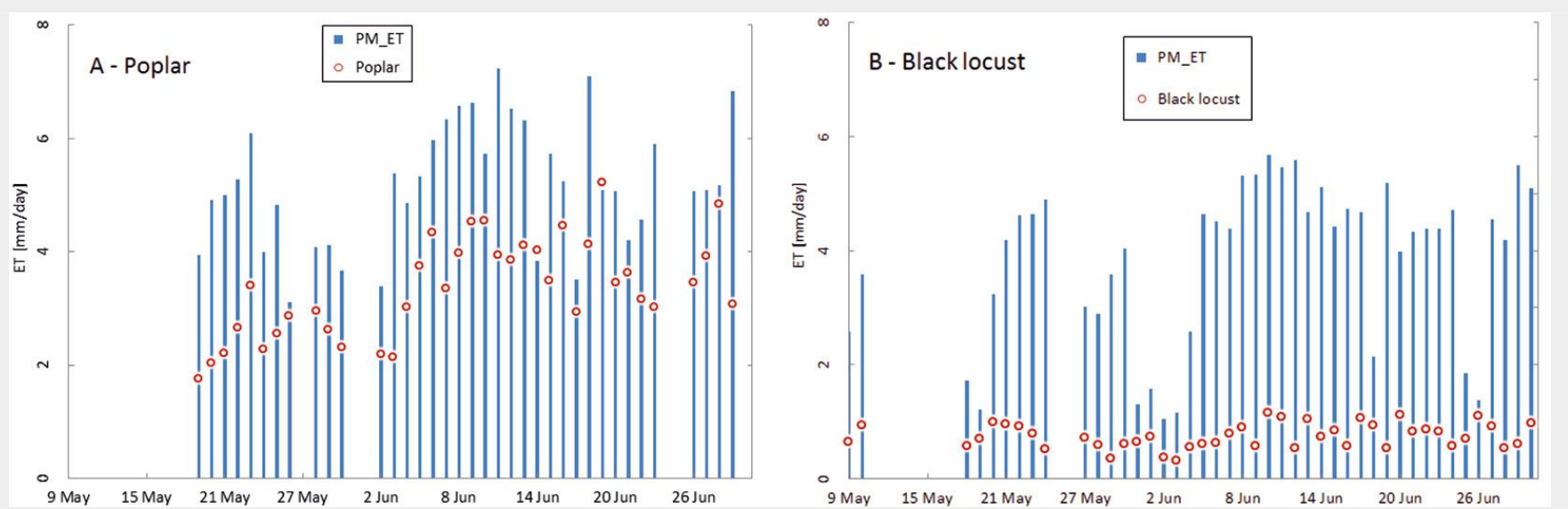

Fig. 5 - Daily ET rates of the poplar (GW well F2) and black locust (GW well F6) plantations. 
Tab. 1 - Correlation coefficients ( $r$ ) between reference $\mathrm{ET}$ and estimated $\mathrm{ET}_{\mathrm{gw}}$ values. (*): Correlation is significant at the 0.1 level (two-tailed); (**): correlation is significant at the 0.01 level (twotailed).

\begin{tabular}{ll}
\hline Plot & r \\
\hline Poplar (GW well 2) & $0.49^{* *}$ \\
Black locust (GW well 6) & $0.35^{*}$ \\
\hline
\end{tabular}

transpiration of the poplar and black locust plantations were compared to PM_ET (Penman-Monteith reference evapotranspiration) for a period in May-June in 2014 (Fig. 5).

Significant daily water table fluctuation suggested a substantial groundwater consumption of the poplar plantation of Nyírbogát. The $\mathrm{ET}_{\mathrm{gw}}$ of the poplar (mean ET rate: $3.6 \mathrm{~mm}^{-1}{ }^{-1}$ ) plantation was about $65 \%$ of the potential evapotranspiration, calculated for the grass reference surface $\left(5.18 \mathrm{~mm} \mathrm{day}^{-1}\right)$. On some days the groundwater ET was almost as high as the reference ET (calculated for a grass reference surface) showing that the higher leaf area index and canopy conductance of the forest canopy induced higher actual ET. The average ET of the black locust plantation was only $0.73 \mathrm{~mm}$ day $^{-1}$, which was about $20 \%$ of the calculated daily potential ET $\left(3.67 \mathrm{~mm} \mathrm{day}^{-1}\right)$.

The groundwater consumption of the studied plantations was less than observed in the various studies of the region, probably due to lower leaf area index and rooting depth. Gribovszki et al. (2014) determined a $7.5 \mathrm{~mm} \mathrm{day}^{-1}$ mean ET rate for a 60 year old oak forest close to Jászjákóhalma in the Jászság region in the exceptionally dry year 2012. The high ET values of that study were the result of the large atmospheric and canopy conductance of that forest plot. In the Northeastern part of the Hungarian Lowland Moricz (2010) measured groundwater consumption up to 5.8 $\mathrm{mm}$ day $^{-1}$ for a 60 year old oak forest in a shallow water table (between 1.3 and $2.5 \mathrm{~m}$ deep) environment. In the central part of the Hungarian Lowland Nosetto et al. (2007) determined a $1.9 \mathrm{~mm} \mathrm{day}^{-1}$ (up to 3.2 $\mathrm{mm} \mathrm{day}^{-1}$ ) groundwater ET for an oak forest. In that study the water table was lower (mean: $5 \mathrm{~m}$ ) and the study period was in autumn.

The correlation coefficient between the reference ET and groundwater ET was not high at either plot (Tab. 1), but was statistically significant. Although there were not any soil moisture measurements available, the medium strong correlation of the poplar showed that the groundwater ET was under the potential ET indicating notable soil moisture also available for transpiration. In case of the black locust the weaker correlation referred to the relatively shallow rooting depth and the recharge of the young plantation.

\section{Conclusions}

$\mathrm{ET}_{\mathrm{gw}}$ of forest covers (poplar and black locust plantations) and adjacent corn-field plots were compared in discharge and recharge zones in the Hungarian Great Plains during a two-month period in 2014.

In the discharge zone the water table under the poplar plantation showed a diurnal pattern with night-time recovery. The roots of the poplar trees were able to reach the groundwater, thereby creating a water table depression and inducing groundwater supply in depths of 3.1-3.3 m. We applied a water table fluctuation method to estimate $\mathrm{ET}_{\mathrm{gw}}$ that incorporated the daily changes of groundwater supply. The mean $\mathrm{ET}_{\mathrm{gw}}$ of the poplar plantation was about $3.6 \mathrm{~mm}$ day $^{-1}$. Contrary, the shallow roots of nearby corn field could not tap the groundwater, therefore neither daily groundwater fluctuation nor $\mathrm{ET}_{\mathrm{gw}}$ were detected.

The water table under the black locust plantation in the recharge zone displayed a step-like pattern, indicating the lack of night-time recovery of water table in similar water table depths of the poplar forest. $\mathrm{ET}_{\mathrm{gw}}$ was simply calculated using the observed water table changes and specific yield without the inclusion of the groundwater supply. The mean $\mathrm{ET}_{\mathrm{gw}}$ of the black locust plantation was $0.7 \mathrm{~mm}$ day $^{-1}$, indicating the ability of groundwater extraction despite the upland location and the shallow rooting depth. Similarly to the discharge zone, $\mathrm{ET}_{\mathrm{gw}}$ was zero in the adjacent corn field.

This study indicates that local estimations of $\mathrm{ET}_{\mathrm{gw}}$ from simple water table measurements could assist to better understanding of groundwater use of varying vegetation types in recharge and discharge zones.

\section{Acknowledgements}

The research was supported by a fund from OTKA (NN 79835), the Postdoctoral Research Program of HAS No. PD-029/2015 and "Agrárklíma.2"(VKSZ_12-1-2013-0034).

\section{References}

Allen RG, Pereira LS, Raes D, Smith M (1998). Crop evapotranspiration - Guidelines for computing crop water requirements. FAO irrigation and drainage paper 56, FAO, Rome, Italy, pp. 300.

Allen CD, Macalady AK, Chenchouni H, Bachelet $D$, McDowell $N$, Vennetier $M$, Kitzberger $T$, Rigling A, Breshears DD, Hogg EH, Gonzalez P, Fensham R, Zhang Z, Castro J, Demidova N, Lim $\mathrm{JH}$, Allard G, Running SW, Semerci A, Cobb N (2010). A global overview of drought and heatinduced tree mortality reveals emerging climate change risks for forests. Forest Ecology and Management 259: 660-684. - doi: 10.1016/ j.foreco.2009.09.001

Andréassian V (2004). Waters and forests: from historical controversy to scientific debate. Journal of Hydrology 291: 1-27. - doi: 10.1016/j.jhy drol.2003.12.015

Andrasevits Z, Buzás GY, Sciberna E (2005). Current afforestation practice and expected trends on family farms in West Hungary. Journal of Central European Agriculture 5: 297-302. Balog K, Kuti L, Szabó A, Tóth T (2014). Sand grain mineralogy and morphology under forest and grassland/arable fields in Eastern Hungary. Agrokémia és Talajtan 63: 49-58. - doi: 10.1556/ Agrokem.63.2014.1.6

Borsy Z, Csongor E, Sárkány S, Szabó I (1981). Phases of blown-sand movements in the NorthEast part of the Great Hungarian Plain. Acta geographica ac geologica et meteorologica, Debrecina 20: 5-33.

Breshears DD, Cobb NS, Rich PM, Price KP, Allen CD, Balice RG, Romme WH, Kastens JH, Floyd ML, Belnap J, Anderson JJ, Myers OB, Meyer CW (2005). Regional vegetation die-off in response to global-change-type drought. Proceedings of the National Academy of Sciences USA 102: 15144-15148. - doi: 10.1073/pnas.050573 4102

Butler JJ, Kluitenberg GJ, Whittemor DO, Loheide SPII, Jin W, Billinger MA, Zhan X (2007). A field investigation of phreatophyteinduced fluctuations in the water table. Water Resources Research 43: W02404.

Drexler JZ, Snyder RL, Spano D, Paw UKT (2004). A review of models and micrometeorological methods used to estimate wetland evapotranspiration, Hydrological Processes 18 (11): 20712101.

Duke HR (1972). Capillary properties of soils'influence upon specific yield. Transactions of the American Society of Agricultural Engineers 15: 688-691. - doi: 10.13031/2013.37986

Ellison D, Futter MN, Bishop K (2012). On the forest cover-water yield debate: from demand- to supply-side thinking. Global Change Biology 18: 806-820. - doi: 10.1111/j.1365-2486.2011.02589.x

Fahle M, Dietrich O (2014). Estimation of evapotranspiration using diurnal groundwater level fluctuations: comparison of different approaches with groundwater lysimeter data. Water Resources Research 50: 273-286. - doi: 10.1002/ 2013WR014472

Falkenmark M, Rockström J (2006). The new blue and green water paradigm: breaking new ground for water resources planning and management. Journal of water resources planning and management 132 (3): 129-132. - doi: 10.1061/ (ASCE)0733-9496(2006)132:3(129)

Freeze RA (1969). The mechanism of natural ground-water recharge and discharge: 1. Onedimensional, vertical, unsteady, unsaturated flow above a recharging or discharging groundwater flow system. Water Resources Research 5 (1): 153-171. - doi: 10.1029/WR005ioo1po0153

Führer E, Járó Z (2005). Az erdovagyon bovítése a mezogazdaságilag gazdaságosan nem hasznosított földterületek beerdosítésével [Forest cover expansion by afforestration of economically non rentable agricultural lands]. In: “Erdofa hasznosítás Magyarországon” (Molnár S ed). University of West Hungary, Sopron, Hungary, pp. 130-136. [in Hungarian]

Gálos B, Lorenz PH, Jacob D (2007). Will dry events occur more often in Hungary in the future? Environmental Research Letters 2: 034006.

Grant GE, Tague CL, Allen CD (2013). Watering the forest for the trees: an emerging priority for managing water in forest landscapes Fron- 
tiers in Ecology and the Environment 11: 314321.

Gribovszki Z, Kalicz P, Szilágyi J, Kucsara M (2008). Riparian zone evapotranspiration estimation from diurnal groundwater level fluctuations. Journal of Hydrology 349: 6-17. - doi: 10.1016/j.jhydrol.2007.10.049

Gribovszki Z, Kalicz P, Balogh K, Szabó A, Tóth T (2014). Comparison of groundwater uptake and salt dynamics of an oak forest and of a pasture on the Hungarian Great Plain. Acta Silvatica et Lignaria Hungarica 10 (1): 103-114.

Gribovszki Z, Szilágyi J, Kalicz P (2010). Diurnal fluctuations in shallow groundwater levels and in streamflow rates and their interpretation - a review. Journal of Hydrology 385: 371-383. - doi: 10.1016/j.jhydrol.2010.02.001

Hoekstra AY, Chapagain AK, Aldaya MM, Mekonnen MM (2009). Water footprint manual: state of the art 2009. Water Footprint Network, Enschede, Netherlands, pp. 206.

ljjász E (1939). A fatenyészet és az altalajvíz, különös tekintettel a nagyalföldi viszonyokra [Forest and groundwater connections in Hungarian Great Plain]. Erdészeti Kísérletek 42: 1107. [in Hungarian]

Jobbágy EG, Jackson RB (2004). Groundwater use and salinization with grassland afforestation. Global Change Biology 10: 1299-1312. - doi: 10.1111/j.1365-2486.2004.00806.x

Keresztesi B (1968). Morphological characteristic of the Robinia root system on different sites of the Great Hungarian Plain. In: "Methods of Productivity Studies in Root Systems and Rhizosphere Organisms 68" (Russian Academy of Sciences ed). International Symposium, Saint
Petersburg, Russia, pp. 89-96.

Lautz LK (2008). Estimating groundwater evapotranspiration rates using diurnal water-table fluctuations in semi-arid riparian zone. Hydrogeology Journal 16: 483-497. - doi: 10.1007/s100 40-007-0239-0

Loheide IISP, Butler JJ, Gorelick SM (2005). Estimation of groundwater consumption by phreatophytes using diurnal water table fluctuations: a saturated-unsaturated flow assessment. Water Resources Research 41: W07030.

Magyar P (1961). Alföldfásítás II [Afforestration in Hungarian Great Plain II]. Akadémiai Kiadó. Budapest, pp. 512. [in Hungarian]

Major P (2002). Síkvidéki erdok hatása a vízháztartásra [Effect of lowland forest on water balance]. Hidrológiai Közlöny 82: 319-324. [in Hungarian]

Matyas CS, Sun G (2014). Forests in a water limited world under climate change. Environmental Research Letters 9: 085001.

Mazur MLC, Wiley MJ, Wilcox DA (2013). Estimating evapotranspiration and groundwater flow from water-table fluctuations for a general wetland scenario. Ecohydrology 7 (2): 378-390. - doi: $10.1002 / e c 0.1356$

Meyboom P (1967). Groundwater studies in the Assiniboine River drainage basin-part II: hydrologic characteristics of phreatophytic vegetation in south-central Saskatchewan. Bulletin of Geological Survey of Canada 139: 65.

Móricz N (2010). Water balance study of a groundwater-dependent oak forest. Acta Silvatica \& Lignaria Hungarica 6: 49-66.

Móricz N, Mátyás C, Berki I, Rasztovits E, Vekerdy Z, Gribovszki Z (2012). Comparative water balance study of forest and fallow plots. iForest - Biogeosciences and Forestry 5: 188-196. doi: 10.3832/iforo624-005

Nosetto MD, Jobbágy EG, Paruleo JM (2005). Land use change and water losses. The case of grassland afforestation across a soil textural gradient in central Argentina. Global Change Biology 11: 1101-1117. - doi: 10.1111/j.1365-2486.20 05.00975.x

Nosetto MD, Jobbágy EG, Tóth T, Di Bella CM (2007). The effects of tree establishment on water and salt dynamics in naturally salt-affected grasslands. Oecologia 152: 695-705. - doi: 10.1007/s00442-007-0694-2

Schilling KE (2007). Water table fluctuations under three riparian land covers, lowa (USA). Hydrological Processes 21: 2415-2424. - doi: 10.1002/hyp.6393

Shah N, Nachabe M, Ross M (2007). Extinction depth and evapotranspiration from ground water under selected land covers. Ground Water 45 (3): 329-338.

Toth J (1962). A theory of groundwater motion in small drainage basins in central Alberta, Canada. Journal of Geophysical Research 67 (11): 4375-4388. - doi: 10.1029/JZ067io11p04375 Toth J (1963). A theoretical analyses of groundwater flow in small drainage basins. Journal of Geophysical Research 68 (16): 4795-4812. - doi: 10.1029/JZo68io16p04795

White WN (1932). Method of estimating groundwater supplies based on discharge by plants and evaporation from soil - results of investigation in Escalante Valley, Utah, US. Geological Survey, Water Supply Paper 659-A, pp. 1-105. 